\title{
An Economic Evaluation of the Massachusetts Forestry Yield Tax Program
}

by

Gary D. Kronrad' ${ }^{1}$ and Patrice A.W. Harou ${ }^{2}$

\begin{abstract}
Owners of 10 or more contiguous acres of forest land in Massachusetts are eligible to classify their property under a modified assessment-yield tax property tax law. This program is designed to increase the flow of timber products by decreasing the costs of engaging in a program of forest management. In return for lower annual property taxes the owner must practise forest management and pay a yield tax.

Benefit-cost ratios, using two marginal analysis decision frameworks, were calculated to evaluate the economic efficiency of this program. The two decision frameworks yielded different results and, therefore, different conclusions about the efficiency of this tax incentive program.
\end{abstract}

Key words: Special forest tax law, yield tax, benefitcost analysis.

\section{Résumé}

Les propriétaires de blocs de 10 acres ou plus de terrains forestiers au Mawssachussetts ont le droit de classifier leur propriété en tenant compte de la législation foncière qui comprend un niveau de taxation basé sur le rendement envisagé et la possibilité. Ce programme est conçu pour accroître la disponibilité des produits forestiers, tout en réduisant les coûts associés au programme d'aménagement forestier. Afin de bénéficier d'un niveau de taxation annuel inférieur, le propriétaire doit mettre en pratique un programme d'aménagement forestier et payer une taxe basée sur la possibilité.

Des ratios coût-bénéfices utilisant deux cadres d'analyse décisionnelle extrêmes, ont été calculés pour évaluer l'efficience économique de ce programme. Les cadres décisionnels donnèrent des résultats différents et, par le fait même, de différentes conclusions au sujet de l'efficience de ce programme incitatif foncier.

Mots clés : Législation spéciale foncière en foresterie, taxe au rendement, analyse coûts-bénéfices.

\section{Introduction}

The annual ad valorem property tax system is generally considered to discourage long-term forest management. To reduce the problems caused by ad valorem taxation of forest lands, nine states, including Massachusetts, now have some form of an optional yield tax. A yield tax is a tax on the value of forest yield. Because payment is made at the time of harvest, yield taxes partly eliminate the "time bias" of the ad valorem tax.

\footnotetext{
Assistant Professor of Forest Resource Economics, Small Woodlot Forestry Research and Development Program, North Carolina State University, Raleigh, NC 27607 .

2Associate Professor of Forest Resource Economics, Department of Forestry and Wildlife Management, University of Massachusetts, Amherst, MA 01003.
}

Massachusetts' forest tax law (Chapter 61 of the General Laws), enacted in 1914 is a modified assessment-yield tax property tax law which provides that owners of 10 or more contiguous acres of forest land, who are willing to manage their land under a planned program, may qualify to have their forest land assessed at not more than $\$ 10$ per acre. In return for this tax savings, the landowner must pay to the local town a yield tax of $8 \%$ of the total revenue received for any products harvested from the forest. To discourage land speculation, the law requires that if the land is "declassified" the landowner must repay any taxes saved plus an interest charge of $8 \%$ per annum thereon up to a total of $\$ 200$ per acre.

Tax relief is generally agreed to be a major incentive to improve forest land management. But does the incentive provided by Chapter 61 bring forth enough benefits to justify the 
opportunity cost of the revenue forgone and the increased state government costs to administer the program? Is Chapter 61 an efficient program for increasing the level of forest management and output on privately owned forest lands in Massachusetts? This paper will address these questions by evaluating the economic efficiency of the program. Economic efficiency compares the social value of the inputs and outputs, disregards transfer payments (Harou 1984a and b), and uses a social discount rate (Harou 1985).

\section{Determining Benefits and Costs: Two Methods}

The first step in evaluating this program was to determine what benefits and costs are attributable to it. Only those benefits and costs that occur because of the program may be attributed to it. Any benefits and costs that would have accrued in its absence cannot be attributed to the program.

To determine what benefits and costs are attributable to the Chapter 61 program, it must be determined which landowners would have managed their land for timber production without Chapter 61 and which would not have managed profitably without Chapter 61. Only the latter group truly "needs" the program to engage profitably in forest management and, therefore, it is only their benefits and costs that are attributed to the program. It is assumed that the group that would have managed without Chapter 61 does not produce any marginal social net benefits.

Determining who "needs" the program is difficult because it is not known what the landowner would do in its absence. This study determined whose benefits and costs are attributable to the Chapter 61 program by using two different methods: the financial analysis decision framework and the questionnaire decision framework.

In the financial analysis decision framework, the analyst determines for the landowner whether or not it was profitable to manage without Chapter 61. A cash flow analysis is made using an inventory of the property, growth projections, complementary information obtained through surveys, and costs and price data. Based on the cash flow analyses, the landowners are classified into two groups as defined by inequalities (1) and (2).

where:

$$
\begin{aligned}
& \left(B_{z}-R_{z}\right)-\left(L_{z}-C_{z}\right) \geqslant 0 \\
& \left(B_{z}-R_{z}\right)-\left(L_{z}-C_{z}\right)<0
\end{aligned}
$$

$B=$ present value of total timber harvested with $a$ program of forest management (discounted with landowner's alternative rate of return).

$R=$ present value of total timber harvested without a program of forest management (discounted with landowner's alternative rate of return).

$\mathrm{L}=$ present value of all labor costs incurred under $a$ program of forest management (discounted with landowner's alternative rate of return).

$\mathrm{C}=$ present value of all labor costs incurred without a program of forest management (discounted with landowner's alternative rate of return).

$z=$ without the Chapter 61 program.

For the landowners for whom inequality (1) holds, the internal rate of return from the marginal timber investment (MRR) is greater than or equal to their alternative rate of return (MRR $\geqslant A R R)$. This means that these landowners could have profitably managed for timber production without Chapter 61 . Chapter 61 is theoretically superfluous to induce management on these properties. In our method, even though these landowners may be participants in the program, the extra timber output (benefits) due to forest management on their property cannot be attributed to it in the economic analysis. This is because these benefits would have accrued to society without the program anyway. Likewise, the forest management labor costs cannot be attributed to the cost of the Chapter 61 program because these landowners would have managed without the program and these costs would have occurred.

For the landowners for whom inequality (2) holds, the marginal rate of return from forest management is less than the alternative rate of return (MRR $<$ ARR). This means that these landowners could not have managed their land for timber production without the Chapter 61 program because they would not have earned or perceived to earn a profit on the investment. Chapter 61 is, therefore, needed to induce these landowners to engage in forest management. For these landowners, the marginal benefits and marginal labor costs of forest management are attributable to the Chapter 61 program in the economic analysis.

To calculate inequalities 1 and 2, the first step was to select a sample of properties. The Massachusetts' Division of Forests and Parks provided a list of the names of owners, property sizes, and location of all properties involved in the Chapter 61 program. A two-stage stratified random sample was used; the first stage of the sample was chosen by county and the second stage was chosen by property size classes within each county. Based on the results of the sampling scheme, 102 forest properties, containing 2345 acres, were selected. This represented $10 \%$ of the properties entering the program in 1978.

A forest inventory was then conducted on the sample forest properties to get present volume and species data. To determine future stand conditions and yields, a growth simulator, MIXUP (Alimi and Barrett 1980), was employed.

The data output from MIXUP was used to construct product-factor tables. These tables, labor costs for the various management activities, which were obtained through a survey of forest consultants (Kronrad et al. 1980), and stumpage prices for the various species, which were obtained from the records of sawmills in Massachusetts and the Division of Forests and Parks, were used to construct cash flow tables. Present values were calculated using the landowner's real alternative rate of return. A questionnaire survey was used to determine each landowner's alternative rate of return. To place all of the forest properties into the same time frame, the data were calculated for an infinite number of rotations using the Faustmann formula.

Results of the financial analysis decision framework show that the marginal rate of return from forest management is less than the landowner's alternative rate of return for $23.5 \%$ of the 102 forest properties used in this study. This means that, given the landowners have decided not to sell their lands (they own their land primarily for reasons other than timber production) and are profit motivated or at least interested in minimizing costs, Chapter 61 theoretically is not necessary to induce these particular landowners to engage in a program of forest management on $76.5 \%$ of the forest properties or $81 \%$ of the acres.

The second method of determining whose benefits and costs are attributable to the Chapter 61 program is the questionnaire decision framework. This decision framework determines whose benefits and costs to count in the economic 
analyses based on the landowner's perceived net benefits at the time that the questionnaire survey was made. The same sample of landowners were used for both decision frameworks.

Based on this second method, the three questions used to classify the landowners were:

1. If Chapter 61 did not exist, would you have managed your land for timber production?

2. If Chapter 61 did not exist, would you have harvested your timber when it was mature?

3. If Chapter 61 did not exist, would you have sold your land?

Any landowner who answered "YES" to question 3 was not included in any further analysis because it was not known what the next owner would do with the land. Therefore, there is no data for the "without" case of the with and without analysis.

Based on the responses, four groups of landowners were distinguished. Those who answered:
1. NO management
2. NO management
3. YES management
4. YES management

NO harvesting
YES harvesting
YES harvesting
NO harvesting

Results of the questionnaire show that without Chapter $61,30 \%$ of the landowners would have sold their land. Of the remaining landowners, $16.7 \%$ would not manage or harvest their land, 23.3\% would not manage but would harvest, $53.3 \%$ would manage and harvest without Chapter 61 , and $6.7 \%$ would manage but not harvest without Chapter 61

A comparison of the results of the two decisions frameworks yields some interesting differences. Based on the results of the financial analysis decision framework, forest management is profitable without Chapter 61 on $76.5 \%$ of the forest properties. Based on the results of the properties questionnaire decision framework, $76.6 \%$ of the landowners believe it is profitable to harvest their timber without Chapter 61 but only $53.3 \%$ believe it is financially profitable to manage their forest lands without Chapter 61.

However, many of the properties that do not need the tax incentive according to the financial analysis decision framework do need the incentive according to the questionnaire. Discrepant benefit-cost ratios will be derived from the two decision frameworks because of the different methods used to identify which properties do or do not need the tax incentive.

\section{Benefit-Cost Analyses}

Having explained the two methods of determining whose benefits and costs to count in the economic analyses, let us turn to the efficiency analysis of the program.

If society gives an incentive in the form of a reduction in taxes, it is expected that the benefits of the tax incentive program to society will be equal to or greater than the opportunity costs and real costs incurred by society. If the costs are greater than the benefits, then the program is an inefficient use of resources and society would be better off without it. To determine whether the social benefits outweigh the social costs, a benefit-cost analysis is performed.

The benefit-cost ratio used to evaluate Chapter 61, and similar in content to one that was used by Mills and Cain
(1978) and Gregersen et al. (1978), is termed Social Efficiency (SE). It is the ratio of the present value of the marginal social benefits induced by the program to the sum of the present value of the marginal social labor costs and the total administrative costs that are attributable to the program. Transfer payments are disregarded and a social discount rate is used. The SE ratio compares all of the social costs to the social benefits and is, therefore, the appropriate ratio to consider when evaluating the efficiency of government programs because it answers the question: Is society economically better off with this particular program?

SE is calculated as follows for the financial analysis decision framework:

$$
S E_{f}=\frac{\Sigma(M B x)}{\Sigma(M L C x)+\Sigma(A C x+y)}
$$

$f=$ financial analysis decision framework

$\mathrm{MB}=$ present value of stumpage harvested with forest management minus present value of stumpage harvested without forest management. Stumpage prices are used as a proxy for social benefits since the market for stumpage is perfectly competitive in Massachusetts. All costs and benefits are discounted using several discount rates which cover a reasonable range of discount rates.

MLC $=$ the present value of the social labor costs with forest management minus the present value of the social labor costs without forest management. The social labor cost, or the shadow wage, reflects the true opportunity costs of the worker to society. The shadow wage is different from the market price of labor when the landowners themselves perform the forestry practices. In this case, the shadow wage has been estimated to be one-half that of a consulting forester.

$A C=$ present value of the administrative costs incurred by the State to administer the program.

$x=$ all landowners who will not earn their alternative rate of return by investing in a program of forest management (MRR $<$ ARR).

$y=$ all landowners who will earn at least their alternative rate of return by investing in a program of forest management (MRR $\geqslant A R R$ ).

SE is calculated as follows for the questionnaire decision framework:

$$
\mathrm{SE}_{\mathrm{q}}=\frac{\Sigma(M B a+b+d)}{\Sigma M L C(a+b+d)+\Sigma A C(a+b+c+d)}
$$

where:

$q=$ questionnaire decision framework

$\mathrm{a}=$ all landowners who, on their questionnaire, responded NO management, NO harvesting without Chapter 61.

$b=$ all landowners who, on their questionnaire, responded NO management, YES harvesting without Chapter 61.

$c=$ all landowners who, on their questionnaire, responded YES management, YES harvesting without Chapter 61.

$d=$ all landowners who, on their questionnaire, responded YES management, NO harvesting without Chapter 61. Output produced by these landowners is attributable to the Chapter 61 program because the program mandates that landowners harvest their timber when it is mature. 
The MB $\mathrm{c}$ and MLC $\mathrm{c}$ are zero because the marginal benefits and labor costs are the same with or without the program.

\section{Results}

Table 1 presents the results of the Social Efficiency benefit-cost analysis calculated with social discount real rates of $0,5,10$, and $15 \%$. With the financial analysis decision framework, the ratio of the marginal social benefits of the Chapter 61 program to the marginal social labor costs plus the administrative costs of the program exceed 1 only when a zero discount rate is used.

A sensitivity analysis was conducted that included Forestry Incentives Program payments (FIP) as a benefit in the calculation of the financial analyses in inequalities 1 and 2. FIP is a federal cost-sharing program authorized by Congress in 1973. Under this program eligible landowners in Massachusetts can receive a cost-share of $75 \%$ of the direct cost of planting, precommercial thinning, understory release, cull tree removal, and/or construction of a fire road. The result of including federal FIP payments in the financial analysis is that less people need the yield tax program to profitably engage in a program of forest management. Under this assumption, the benefit-cost ratios are less than one even at a zero discount rate (Table 1).

These two sets of SE ratios (those calculated with and without FIP payments), show that the level of efficiency of a program is sometimes dependent on other incentive programs that are already available. It is, therefore, recommended that a program should not be judged in isolation from other programs with the same objectives and the same recipients.

With the questionnaire decision framework, the SE ratio is greater than one regardless of the social discount rate used.

The reason for the difference between the SE ratios derives from the fact that under the questionnaire decision framework some landowners said that they would not have engaged in what would otherwise be a profitable program of forest management if they had not been lured into it by the promise of lower annual taxes. In calculating the SE ratios, the marginal benefits from these productive sites increase the numerator substantially.

For any of the calculated SE ratios, changing the shadow wage of labor to a market wage did not change the benefitcost ratios by more than 0.01 .

It is expected that a benefit-cost ratio will decrease with increasing discount rates. However, the sensitivity analysis of the discount rate reported in Table 1 shows that this is not always so. Participants in the Chapter 61 program harvest timber throughout the rotation. Because of the history and natural factors (hurricane of 1938) that have influenced forest resources in the State, most of the forests in Massachusetts are approaching maturity. Many landowners now have timber that is of saleable size, some of which should be cut immediately for proper management. This translates into benefits accruing to the Chapter 61 program at the present time or in the near future. Discounting these benefits results in a small change in magnitude. But costs occur regularly throughout the rotation and especially toward the end of the rotation. Because of the timing of the benefits and costs, the discount rate affects the results of the benefit-cost ratios in an unusual manner. With increasing discount rates, the benefits are reduced at a slower rate than the costs due to the timing of the benefits and costs.

\section{Conclusions}

An efficiency benefit-cost ratio, using two different decision frameworks, was used to compare the marginal social costs and benefits of a modified assessment-yield tax program. The financial analysis decision framework assumes that the landowners have perfect information and the expertise, or access to it, necessary to project their cash flows with and without forest management. If the marginal rate of return from management is greater than the landowner's alternative rate of return, then theoretically the tax incentive is not needed to induce the landowner to engage in a planned program of forest management.

The questionnaire decision framework asks the landowners directly whether or not they would have managed their forest without the tax incentive program. Social marginal benefits and costs are calculated based upon the landowners' responses. One could argue that this decision framework is the more appropriate method to employ because the decision to manage is made on the expected long-term profitability perceived (but not necessarily realized) by the landowner.

The two decision frameworks yield different results and, therefore, different conclusions about the efficiency of this tax incentive program. The financial analysis decision framework yields benefit-cost ratios less than unity except at a zero discount rate without Forestry Incentives Program (FIP) payments. The questionnaire decision framework yields benefitcost ratios greater than 2 for all discount rates. This is so because under this method many landowners believed that forest management was not profitable on their lands when, in fact, it was. These profitable properties increase the numerator of the benefit-cost ratios.

The use of the financial analysis decision framework indicates that the social costs are greater than the social benefits of the Chapter 61 program at real social discount

Table 1. The decision frameworks, their assumptions, and the Social Efficiency ratios.

\begin{tabular}{|c|c|c|c|c|c|}
\hline \multirow{3}{*}{ Decision framework } & \multirow[b]{3}{*}{ Assumptions } & \multicolumn{4}{|c|}{ Social efficiency ratios } \\
\hline & & \multicolumn{4}{|c|}{ Discount rates (percent) } \\
\hline & & 0 & 5 & 10 & 15 \\
\hline \multirow[t]{2}{*}{ Financial Analysis: } & $\begin{array}{l}\text { - As specified in inequalities } 1 \text { and } 2 \text {, and } \\
\text { equation } 3 \\
\text { - Forestry Incentives Program payments are }\end{array}$ & 1.67 & .91 & .77 & .70 \\
\hline & considered revenue in inequalities 1 and 2 & .99 & .84 & .86 & .84 \\
\hline Questionnaire: & - As specified in inequation 4 & 2.15 & 2.56 & 2.31 & 2.14 \\
\hline
\end{tabular}


rates equal to or greater than $5 \%$. The social benefits are greater than the social costs of the program when the questionnaire decision framework is used to calculate the benefitcost ratios. These two decision frameworks could have been reconciled if, after conducting the questionnaire survey,the properties that would not have been managed without the tax incentive would have been re-examined using the financial analysis decision framework. In this case the benefit-cost ratios would have been below unity. This would indicate that the program is inefficient because the social value of the inputs are greater than the social value of the program outputs.

The comparison of the results of these two decision frameworks shows that several nonindustrial private forest landowners did not manage when it would have been profitable for them to do so. Such information is useful for formulating and targeting other more cost-effective types of programs, like extension, at these types of landowners.

The Chapter 61 program could become a more efficient program if periodic management costs are decreased and/or administrative costs are reduced. In addition, it has been calculated that the tax incentive can be curtailed, by increasing the yield tax or annual property tax, without significantly reducing the number of participants in the program, i.e., the number of properties that break-even in the financial analysis. The average landowner in this study will save approximately $75 \%$ of this total property tax bill over one rotation by enrolling in Chapter 61. On a yearly basis the average landowner saved $\$ 11.68$ per acre in taxes or $91 \%$ of his annual tax bill. (The difference between the yearly and rotational tax savings is due to the yield tax.)
Another way to increase the efficiency of this yield tax program is to prohibit the cumulation of the various forestry incentives that are available. The cost-sharing Forestry Incentives Program payments are great enough to allow some landowners to break-even in the financial analysis. Supplementary incentives to these landowners are redundant.

\section{References}

Alimi, Richard J. and James P. Barrett. 1980. Computer and tabular growth simulation of mixed conifer-hardwood stands in the Northeast. Research Report No. 61. New Hampshire Agricultural Exp. Sta., Univ. New Hampshire, Durham, New Hampshire. $56 \mathrm{p}$.

Gregersen, H., T. Houghtaling, and A. Rubinstein. 1978. Economics of public forestry incentives programs: a case study of cost sharing in Minnesota. Res. Pap. (Unpub.), Univ Minnesota, Minneapolis, MN. 138 p.

Harou, P.A. 1984a. Possibilities for shadow pricing forestry incentives. J. For. Ecol. and Manag. 8: 59-73.

Harou, P.A. 1984b. Evaluation of forestry programs: The with-without analysis. Can. J. For. Res. 14:506-511.

Harou, P.A. 1985. On a social discount rate for forestry. Can. J. For. Res. (In press.)

Kronrad, Gary D., Patrice A.W. Harou and Robert J. Mack. 1980. Consulting foresters' fees in Massachusetts. The Northern Logger and Timber Processor 29: 12-16.

Kingsley, Neal P. 1976. The forest-land owners of southern New England. USDA For. Serv., Northeast. For. Exp. Stn. Resour. Bull. NE-41, $27 \mathrm{p}$.

Mills, T.J. and D. Cain. 1978. Timber yield and financial return performance of the 1974 Forestry Incentives Program. USDA For. Serv., Rocky Mountain For. and Range Exp. Sta. Res. Pap. $\mathrm{RM}-204,56 \mathrm{p}$.

\section{EDWARD $S$. FELLOWS

\section{FORESTRY \& FOREST PRODUCTS CONSULTANT}

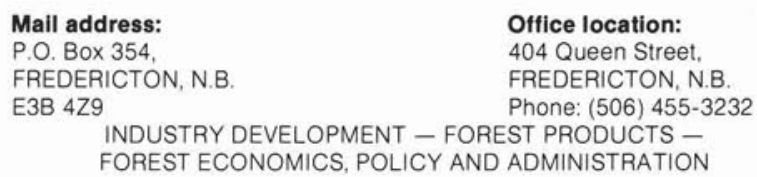

